\title{
\begin{tabular}{l|l|l}
\hline 12 & Jurnal Kependidikan Dasar & Volume. 1 \\
& Nomor. 1 \\
\hline
\end{tabular}
}

\section{Pembelajaran Fisika Dasar Terintegrasi Nilai-Nilai Pendidikan Islam Melalui Diagram Vee}

\author{
Faninda Novika Pertiwi \\ IAIN Ponorogo \\ Email: faninda novik@yahoo.com
}

\begin{abstract}
Abstrak
Penelitian ini dilatar belakangi oleh pembelajaran fisika yang selama ini dilakukan kurang bermakna. Selama ini pembelajaran fisika yang dilakukan belum pernah diintegrasikan dengan nilai-nilai pendidikan islam dan kurang melibatkan peserta didik dengan maksimal. Berdasarkan hal tersebut, makapada penelitian ini peneliti ingin mengimplementasikan pembelajaran fisika dasar terintegrasi nilai-nilai pendidikan islam melalui diagramVee dengan tujuan agar tercipta pembelajaran yang bermakna.Penelitian ini merupakan penelitian tindakan kelas yang dilakukan selama 2 siklus.Materi fisika yang disampaikan pada penelitian ini adalah kesetimbangan benda tegar, kalor, fluida dan gelombang.Subjek penelitiannya adalah mahasiswa IAIN Ponorogo, Jurusan Tarbiyah Prodi tadris IPA yang berjumlah 38 mahasiswa.Data hasil penelitian berupa hasil angket yang berkaitan dengan pembelajaran yang telah dilakukan.Berdasarkan hasil angket, terlihat bahwa setiap indikator dari pembelajaran bermakna mengalami peningkatan dari siklus 1 ke siklus 2. Peningkatan paling kecil terlihat pada indikator kemampuan menemukan jawaban sendiri dari suatu permasalahan yang ada yaitu sebesar 0,6\%. Sedangkan peningkatan paling besar terlihat pada indikator kemampuan menghubungkan materi baru yang dipelajari dengan pengetahuan sebelumnya mengalami peningkatan paling besar yaitu sebesar 12,5\%. Untuk indikator kemampuan menghubungkan materi yang dipelajari dengan salah satu ayat dalam Al-Qur'an mengalami peningkatan sebesar $9 \%$ dan yang terakhir indikator kemampuan mengaplikasikan materi yang dipelajari dalam kehidupan sehari-hari mengalami peningkatan sebesar 6,5\%. Secara keseluruhan, hasil penelitian menunjukkan bahwa pembelajaran bermakna dapat tercapai dengan mengintegrasikan materi fisika dengan ayat Al-Qur'an yang sesuai.Karena dengan begitu peserta didik lebih menghargai dan meyakini keteraturan alam ciptaan Tuhan. Hal ini sesuai dengan tujuan pendidikan IPA di Indonesia yaitu agar peserta didik memiliki keyakinan keteraturan alam ciptaan-Nya dan keagungan Tuhan YME
\end{abstract}

Kata Kunci: Pembelajaran fisika, pendidikan Islam, diagram Vee

\section{A. PENDAHULUAN}

Pendidikan merupakan usaha sadar dan direncanakan dalam rangka mewujudkan suasana belajar dan proses pembelajaran agar peserta didik secara aktif mengembangkan potensi yang ada pada dirinya untuk dapat memiliki kekuatan spiritual keagamaan, pengendalian diri, kepribadian, kecerdasan, akhlaq mulia, serta berbagai ketrampilan yang diperlukan untuk dirinya, 
masyarakat, bangsa dan negara ${ }^{1}$. Semakin majunya ilmu pengetahuan dan teknologi pada saat ini membuat pemerintah terus berupaya meningkatkan kualitas pendidikan. Kualitas pendidikan akan meningkat salah satunya dengan meningkatkan sumber daya manusia. Upaya yang telah dilakukan pemerintah untuk meningkatkan SDM melalui pembaharuan kurikulum yang didalamnya terdapat pembelajaran yang bermakna.

Pembelajaran fisika yang dilakukan di kelas hendaknya bermakna. Pembelajaran yang bermakna diperoleh dari proses ${ }^{2}$. Pembelajaran yang bermakna adalah pembelajaran yang lebih berpusat pada peserta didik.Peserta didik lebih diberikan kesempatan untuk mengkonstruksi pengetahuannya secara mandiri. Fisika merupakan ilmu yang mempelajari fenomena alam, Ilmu yang sangat berman-faat dalam kehidupan sehari-hari. Sehingga pada pembelajarannya hendaknya lebih berpusat pada peserta didik dan konteks-tual. Selain itu, karena berhubungan dengan alam maka pembelajaran fisika tidak hanya bertujuan untuk membekali peserta didik dengan ilmu tetapi juga bertujuan untuk menciptakan peserta didik yang mengagungkan kebesaran Allah ${ }^{3}$. Oleh karena itu, dalam pembelajarannya harus ada nilai-

\footnotetext{
${ }^{1}$ DEPDIKNAS, “Undang-Undang RI No 29 Pasal 1 Tahun 2003" (DEPDIKNAS, 2003).

${ }^{2}$ Burhan Yasin Nurhadi and Agus Gerrad Senduk, Pembelajaran Kontekstual Dan Penerapannya Dalam KBK (Malang: UM Press, 2004).

${ }^{3}$ Sri Latifah, Eka Setiawati, and Abdul Basith,

“Pengembangan Lembar Kerja Peserta Didik (LKPD)

Berorientasi Nilai-Nilai Agama Islam Melalui

Pendekatan Inkuiri Terbimbing Pada Materi Suhu Dan

Kalor," JURNAL ILMIAH PENDIDIKAN FISIKA AL-BIRUNI

5, no. 1 (2016): 43-52.
}

nilai pendidikan islam yang dimasukkan ke dalamnya.

Pendidikan islam merupakan suatu usaha sadar dalam membentuk kepribadian manusia muslim untuk mengubah tingkah lakunya ke arah yang lebih baik atas dasar nilai-nilai ajaran Islam demi mengangkat derajat. Nilai-nilai yang terkandung dalam pendidikan islam adalah nilai aqidah, nilai syariah, dan nilai akhlak. Nilai Aqidah (keyakinan) berhubungan secara vertikal dengan Allah SWT (Hablun Min Allah). Nilai Syari'ah (pengalaman) implementasi dari aqidah hubungan horizontal dengan manusia (Hablun Min an-Naas). Nilai Akhlaq (etika vertika horizontal) yang merupakan aplikasi dari aqidah dan muamalah ${ }^{4}$. Berdasarkan ketiga nilai diatas, yang ingin ditanamkan melalui proses pendidikan dalam ajaran agama Islam yaitu nilai tentang ketaatan kepada Allah SWT dan nilai yang mengatur hubungan sesama manusia.

IAIN Ponorogo adalah sebuah institusi pendidikan agama islam negeri yang berdiri sejak tanggal 21 Maret 1997, berlokasi di kabupaten Ponorogo Jawa Timur. IAIN Ponorogo merupakan perguruan tinggi islam negeri yang menyelenggarakan pendidikan akademik dalam disiplin ilmu keagamaan islam dan disiplin ilmu lainnya seperti IPA, IPS, dan Bahasa Inggris. Sebagai perguruan tinggi islam yang didalamnya terdapat disiplin ilmu umum seperti IPA, IPS, dan Bahasa Inggris,

\footnotetext{
${ }^{4}$ Ali Khalid Ali Bawaneh, Ahmad Nurulazam Md Zain, and Munirah Ghazali, "The Effectiveness of Conflict Maps and the V-Shape Teaching Method in Science Conceptual Change among Eighth-Grade Students in Jordan," International Education Studies 3, no. 1 (2010): 96.
} 
maka pengintegrasian ilmu agama islam kedalam pembelajaran umum sangat penting untuk dilakukan.

Melalui pengintegrasian ilmu agama ke dalam ilmu IPA khususnya fisika diharapkan peserta didik mampu menyatukan arti kehidupan di dunia dan akhirat. Konsep-konsep yang dipelajari di fisika sebenarnya adalah sunnatullah tentang alam semesta, dan untuk meningkatkan keimanan dan ketaqwaan kepada sang pencipta, adalah dengan memberikan makna konsep-konsep fisika berdasarkan nilai-nilai agama yang relevan dengan materi yang disampaikan pada saat pembe-lajaran berlangsung5. Pembelajaran fisika yang dilakukan di kelas akan lebih bermakna jika dalam mengajarkan materi-materi fisika disisipkan nilai-nilai pendi-dikan islam didalamnya. Melalui pembe-lajaran yang terintegrasi antara fisika dan pendidikan islam peserta didik akan mendapatkan berbagai pengalaman belajar dan berbagai ranah pengetahuan.Pembelajaran yang diimplementasikan pada penelitian ini adalah pembelajaran Fisika Dasar dengan diintegrasikan nilai-nilai pendidikan islam menggunakan Diagram Vee.

Diagram Vee merupakan sebuah diagram yang mempunyai sisi konseptual (berpikir) dan sisi metodologis (bekerja). Diagram Vee dapat digunakan oleh siswa dan guru di kelas maupun di laboratorium ${ }^{6}$. Berdasarkan penelitian

\footnotetext{
${ }^{5}$ Latifah, Setiawati, and Basith, "Pengembangan Lembar Kerja Peserta Didik (LKPD) Berorientasi NilaiNilai Agama Islam Melalui Pendekatan Inkuiri Terbimbing Pada Materi Suhu Dan Kalor." ${ }^{6}$ Bawaneh, Zain, and Ghazali, "The Effectiveness of Conflict Maps and the V-Shape Teaching Method in
}

Keles dkk, Diagram Vee dapat digunakan siswa untuk menyimpan pengetahuannya dalam piki-rannya ${ }^{7}$ Sehingga pembelajaran akan bermakna karena pengetahuan yang diperoleh peserta didik akan tahan lama dan mampu diaplikasikan kedalam kehi-dupan sehari-hari. Olehkarena itu pada penelitian ini akan diimplementasikan pembelajaran Fisika Dasar menggunakan diagram Vee. Sehingga penelitian ini berjudul "Implementasi Pembelajaran Fisika Dasar Terintegrasi Nilai-Nilai Pendidikan Islam Melalui Diagram Vee Untuk Mencip-takan Pembelajaran Yang Bermakna".

\section{B. METODE PENELITIAN}

Penelitian ini merupakan penelitian tindakan kelas. Tindakan yang diterapkan dalam PTK ini adalah implementasi pembe-lajaran Fisika Dasar terintegrasi nilai-nilai pendidikan islam melalui diagram Vee untuk menciptakan pembelajaran yang bermakna. Penelitian ini terdiri dari 2 siklus. Siklus pertama dan siklus kedua saling berkaitan. Dalam 1 siklus terdiri dari empat tahap, yaitu tahap perencanaan, tahap tindakan, tahap observasi, dan tahap refleksi.

Pelaksanaan penelitian dilakukan secara bertahap, siklus 1 membahas materi kesetimbangan benda tegar dan kalor, dilanjutkan siklus 2 membahas tentang fluida dan gelombang. Pada siklus

Science Conceptual Change among Eighth-Grade Students in Jordan."

7Özgül Keleş and Sibel Özsoy, "Pre-Service Teachers' Attitudes toward Use of Vee Diagrams in General Physics Laboratory," International Electronic Journal Environmental Education 1, no. 3 (2009), http://dergipark.ulakbim.gov.tr/iejeegreen/article/do wnload/5000133234/5000122068. 
pertama dibuat perencanaan yang berkaitan dengan materi kesetimbangan benda tegar dan kalor. Setelah perencanaan dibuat, maka dilakukan tindakan sesuai dengan yang telah direncanakan. Pada saat berlang-sungnya tindakan dilakukan observasi dan refleksi untuk mengetahui hal-hal yang perlu diperbaiki pada siklus pertama. Setelah siklus pertama selesai, maka dilanjutkan siklus kedua dengan melakukan perbaikan-perbaikan berdasarkan hasil refleksi dari siklus pertama. Pada siklus kedua dibuat perencanaan yang berkaitan dengan materi fluida dan gelombang. Setelah perencanaan dibuat maka dilakukan tindakan sesuai dengan yang telah direncanakan. Selanjutnya dilakukan obser-vasi dan refleksi atas tindakan pada siklus kedua. Berdasarkan hasil siklus pertama dan siklus kedua dilihat apakah tujuan pembelajaran dalam menciptakan pembe-lajaran yang bermakna telah tercapai atau belum.

Faktor yang diteliti dalam penelitian ini adalah langkah-langkah pembelajaran Fisika Dasar yang terintegrasi dengan nilai-nilai pendidikan islam dan terciptanya pembelajaran yang bermakna yaitu peserta didik mampumenghubungkan materi baru yang dipelajari dengan pengetahuan sebelumnya, mampu mengaplikasikan materi yang dipelajari dalam kehidupan seharihari, mampu menghubungkan materi yang dipelajari dengan salah satu ayat dalam AlQur'an, dan mampu menemukan jawaban sendiri dari suatu permasalahan yang ada. Pembelajaran bermakna yang diterapkan yaitu dengan menggunakan diagram Vee.
Sumber data pada penelitian ini adalah mahasiswa Institut Agama Islam Negeri (IAIN) Ponorogo jurusan tadris IPA yang berjumlah 38 orang. Instrumen perlakuan dalam penelitian ini terdiri dari skenario pembelajaran tiap pertemuan dan format Diagram Vee. Instrumen pengukuran yang digunakan untuk memperoleh data adalah menggunakan angket. Angket dibagikan kepada peserta didik pada tiap akhir siklus. Angket yang digunakan adalah angket terbuka, yang didalamnya berisi pertanyaan-pertanyaan yang berkaitan dengan pembelajaran fisika materi kesetimbangan benda tegar, kalor, fluida, dan gelombang. Angket ini digunakan untuk mengetahui pendapat peserta didik tentang pembelajaran yang telah dilakukan. Selain itu, angket ini juga digunakan untuk mengetahui sejauh mana keterlaksanaan pembelajaran Fisika Dasar dengan diagram Vee ini dalam upaya untuk menciptakan pembelajaran bermakna.

Teknik analisis data yang digunakan yaitu menggunakan skala likert kemudian dihitung persentasenya. Skor yang diperoleh melalui angket kemudian dijum-lah, dirata-rata dan dihitung persentase keterlaksanaanya terhadap nilai ideal dari jumlah keseluruhan aspek yang diamati dengan menggunakan persamaan persen-tase menurut Arikunto $^{8}$ :

Persentase $=\frac{\text { Jumlah nilai pembelajaran }}{\text { Jumlah nilai keterlaksanaan pembelajaran }} \times 100 \%$

\footnotetext{
${ }^{8}$ Arikunto Suharsimi and others, "Penelitian Tindakan Kelas," Jakarta: Bumi Aksara, 2006.
} 
Setelah itu data diklasifikasikan menurut tabel klasifikasi keberhasilan pelaksanaan pembelajaran sebagai berikut ${ }^{9}$.

Tabel 1. Kriteria Keberhasilan Pelaksanaan Pembelajaran

\begin{tabular}{lll}
\hline NO & Persentase & Klasifikasi \\
\hline 1 & $81-100$ & Baik Sekali \\
2 & $61-80$ & Baik \\
3 & $41-60$ & Cukup \\
4 & $21-40$ & Kurang \\
5 & $<21$ & Kurang Sekali \\
\hline
\end{tabular}

\section{PEMBELAJARAN BERMAKNA}

Pembelajaran bermakna yang dimaksud dalam kurikulum 2013 adalah proses pembelajaran yang menggunakan pendekatan saintifik, yaitu melalui langkah-langkah: mengamati, menanya, menalar, mencoba, dan mengkomunikasikan. Pembelajaran bermakna akan terwujud jika terjadi situasi pembelajaran yang paling ideal, yaitu keaktifan peserta didik maksimal dan pendidik sangat siap mengajar dengan metode dan persiapan yang matang dalam mengajar. Pembelajaran bermakna merupakan suatu proses dikaitkannya informasi baru pada konsep konsep relevan yang terdapat dalam struktur kognitif seseorang. Ausubel dan Robinson dalam memberikan batasan antara belajar bermakna (meaningful learning) dengan belajar menghafal (rote learning). Dalam belajar bermakna ada dua hal penting yang pertama yaitu bahan

\footnotetext{
${ }^{9}$ Patmawati, “Penerapan Model Inkuiri Dengan Siklus Belajar Dalam Pembelajaran Biologi Untuk Meningkatkan Kerja Ilmiah Dan Prestasi Belajar Kognitif Siswa Kelas XII IPA 3 SMAN Purwosari" 2006, http://library.um.ac.id/ptk/index.php?mod=detail\&id $=55417$.
}

yang dipelajari, dan yang kedua adalah struktur kognitif yang ada pada individu ${ }^{10}$.

Implikasi pembelajaran bermakna adalah terjadinya konflik kognitif. Konflik kognitif terjadi saat interaksi antara konsepsi awal yang telah dimiliki siswa dengan fenomena baru yang dapat diintegrasikan, sehingga diperlukan perubahan atau modifikasi stuktur kognitif (skemata) untuk mencapai keseimbangan ${ }^{11}$. Peristiwa ini akan terjadi secara berkelanjutan selama siswa menerima pengetahuan baru. Oleh karena itu, agar terjadi pembelajaran yang bermakna maka pendidik harus selalu berusaha mengetahui dan menggali konsep yang telah dimiliki siswa dan membantu memadukannya secara harmonis konsep-konsep tersebut dengan pengetahuan baru yang akan diajarkan. Dengan kata lain, belajar akan lebih bermakna jika anak menemukan sendiri konsep yang sedang dipelajarinya atau mengalami langsung apa yang dipelajarinya dengan mengaktifkan lebih banyak indera daripada hanya sebagai pendengar.

Pembelajaran bermakna yang diimplementasikan pada penelitian ini adalah dengan mengintegrasikan nilainilai pendidikan agama islam ke dalam pembe-lajaran Fisika Dasar menggunakan diagram Vee. Pada tahap pembelajarannya, peserta didik diminta untuk berkelompok dan pendidik membagikan diagram Vee kepada tiap peserta didik pada masing-masing kelompok. Pendidik

\footnotetext{
${ }^{10}$ Sukmadinata Syaodih Nana, Landasan Psikologi Proses Pendidikan (Bandung: PT Remaja Rosdakarya, 2009).

${ }^{11}$ Karli, H dan Sriyuliaratnaningsih, Implementasi Kurikulum Berbasis Kompetensi (Bandung: Rosdakarya, 2004).
} 
memberikan petunjuk pengisian diagram Vee dan hal-hal yang harus dilakukan peserta didik selama pembelajaran. Diagram Vee yang harus diselesaikan pada pertemuan pertama berkaitan dengan materi kesetimbangan benda tegar, pertemuan kedua berkaitan dengan kalor, pertemuan ketiga berkaitan dengan fluida, dan pertemuan keempat berkaitan dengan gelombang. Siklus pertama mencakup pertemuan pertama dan kedua, siklus kedua mencakup pertemuan ketiga dan keempat. Setelah pertemuan pertama dan kedua diadakan tes untuk mengetahui penguasaan konsep peserta didik dan setelah itu peserta didik diminta mengisi angket untuk mengetahui respon peserta didik terhadap pembelajaran yang telah dialami.

\section{DIAGRAM VEE}

Diagram Vee yang diberikan pada peserta didik mempunyai dua sisi yaitu sisi konseptual dan metodologi, Diagram Vee merupakan sebuah diagram yang mempunyai sisi konseptual (berpikir) dan sisi metodologis (bekerja). Kedua sisi Diagram Vee menekankan aspek belajar yang saling bergantung yaitu teori (thinking) dan praktik (doing) ${ }^{12}$.Diagram Vee yang digunakan pada penelitian ini tidak sama persis dengan format aslinya. Pada format aslinya, bagian sisi konseptual mencakup definisi dan konsep, sedangkan pada bagian metodologi mencakup klaim pengetahuan, transformasi, dan catatat. Sedangkan pada

\footnotetext{
${ }^{12}$ Budi Utami, “Pengaruh Strategi Peta Konsep Dan Diagram Vee Terhadap Hasil Belajar Siswa Pada Pokok Bahasan Larutan Penyangga Yang Diukur Dengan Authentic Assessment." 2009, http://karyailmiah.um.ac.id/index.php/disertasi/article/view/841.
}

bagian tengah mencakup pertanyaan fokus dan objek/peristiwa. Diagram Vee yang dipakai pada penelitian ini tidak sama persis dengan format tersebut tetapi merupakan modifikasi dari format diagram Vee aslinya.

Diagram Vee ini dimodifikasi sesuai tujuan yang ingin dicapai pada penelitian. Pada sisi konseptual memuat tentang definisi dan konsep, sedangkan pada bagian metodologi memuat tentang Jawaban permasalahan, dan integrasi materi dengan ayat dalam Al-Qur'an. Pada bagian tengah diagram Vee berkaitan dengan fokus pertanyaan dan pada ujung bawahnya berkaitan dengan aplikasi materi dalam kehidupan sehari-hari. Salah satu contoh diagram Vee yang dibuat oleh peserta didik dapat dilihat pada gambar 1 .

Diagram Vee pada gambar 1 merupakan salah satu diagram Vee yang dibuat oleh peserta didik. Peserta didik melengkapi diagram Vee ini pada setiap pertemuan dengan materi yang berbedabeda pada setiap pertemuan. Setelah Diagram Vee diselesaikan oleh peserta didik, hasilnya dibahas bersama-sama dan diperbaiki jika masih ada yang kurang. Diagram Vee ini dapat digunakan pendidik untuk mengetahui kemampuan yang dimiliki peserta didiknya. Kemampuan dalam menghubungkan konsep baru dengan pengetahuan lama maupun kemampuan peserta didik dalam mengintegrasikan ayat Al-Qur'an ke dalam materi yang sedang dipelajari. Melalui penyelesaian Diagram Vee tersebut dengan baik, maka peserta didik akan mengalami pembelajaran yang bermakna daripada hanya sekedar pasif menerima 
materi dan mendengarkan ceramah dari pendidik.

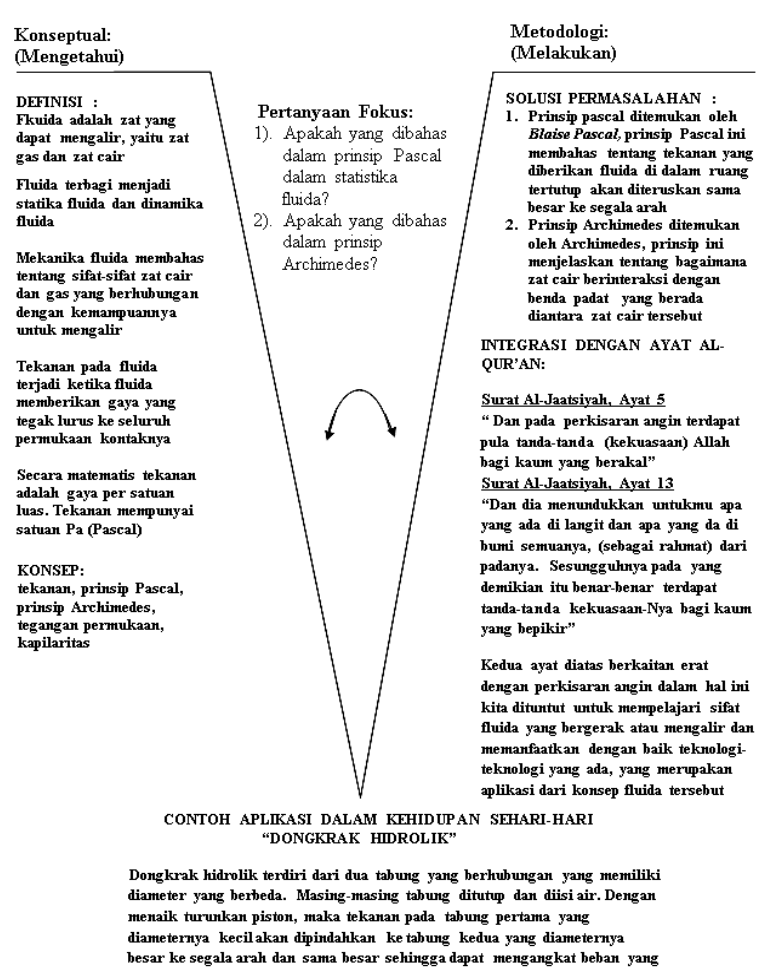

Gambar 1. Gambar diagram Vee yang dihasilkan

Selain menyelesaikan Diagram Vee, peserta didik diminta untuk mengisi angket yang berkaitan dengan pembelajaran yang telah dilakukan. Pengisian angket ini dilakukan setelah dua pertemuan (1 siklus) dilalui. Hal ini untuk mengetahui keterlaksanaan pembelajaran bermakna yang telah dilakukan.Begitu pula setelah siklus 2, peserta didik diminta kembali untuk mengisi angket yang sama seperti angket yang diisi setelah selesai siklus 1. Hasil angket yang berkaitan dengan pembelajaran bermakna yang dialami peserta didik disajikan pada tabel 2 dibawah ini.
Tabel 2. Hasil angket peserta didik tentang pembelajaran bermakna padasiklus 1 dan siklus 2

\begin{tabular}{|c|c|c|c|c|}
\hline \multirow{2}{*}{ Keterangan } & \multicolumn{2}{|c|}{ Skor } & \multicolumn{2}{|c|}{ Persentase } \\
\hline & Siklus 1 & Siklus 2 & Siklus 1 & Siklus 2 \\
\hline $\begin{array}{l}\text { Kemampuan } \\
\text { menghubungkan } \\
\text { materi baru } \\
\text { yang dipelajari } \\
\text { dengan pengeta- } \\
\text { huan sebelum- } \\
\text { nya }\end{array}$ & 524 & 619 & $68,9 \%$ & $81,4 \%$ \\
\hline $\begin{array}{l}\text { Kemampuan } \\
\text { mengaplikasikan } \\
\text { materi yang di- } \\
\text { pelajari dalam } \\
\text { kehidupan } \\
\text { sehari-hari }\end{array}$ & 568 & 617 & $74,7 \%$ & $81,2 \%$ \\
\hline $\begin{array}{l}\text { Kemampuan } \\
\text { menghubungkan } \\
\text { materi yang di- } \\
\text { pelajari dengan } \\
\text { salah satu ayat } \\
\text { dalam Al-Qur'an }\end{array}$ & 572 & 641 & $75,3 \%$ & $84,3 \%$ \\
\hline $\begin{array}{l}\text { Kemampuan } \\
\text { menemukan } \\
\text { jawaban sendiri } \\
\text { dari suatu per- } \\
\text { masalahan yang } \\
\text { ada }\end{array}$ & 600 & 638 & $78,9 \%$ & $79,5 \%$ \\
\hline Total & 2264 & 2515 & $74,5 \%$ & $82,7 \%$ \\
\hline
\end{tabular}

Berdasarkan hasil angket pada tabel 2 diatas, dapat dilihat bahwa setiap indikator dari pembelajaran bermakna mengalami peningkatan dari siklus $1 \mathrm{ke}$ siklus 2. Peningkatan paling kecil terlihat pada indikator kemampuan menemukan jawaban sendiri dari suatu permasalahan yang ada yaitu sebesar 0,6\%. Hal ini karenapesertadidik merasa kesulitan dalam menyelesaikan suatu permasalahan tanpa panduan pendidik. Selama ini peserta didik selalu mengandalkan pendidik dalam menyelesaikan permasalahan atau latihan soal yang ada, peserta didik malas untuk mencoba terlebih dahulu jika diberikan suatu permasalahan. Pada pembelajaran menggunakan diagram Vee kali ini peserta didik diminta untuk menuliskan permasalahan yang ada dipikirannya berkaitan dengan materi 
yang dipelajari,kemudian menyelesaikannya sen-diri terlebih dahulu sampai tuntas. Setelah selesai semua baru dibahas secara bersama-sama. Sehingga peserta didik benar-benar berpikir dan berusaha untuk menyele-saikannya karena selain agar dibahas oleh pendidik, permasalahan yang ada juga berasal dari peserta didik itu sendiri.

Berdasarkan hasil angket pada tabel 2 diatas, dapat dilihat bahwa indikator kemampuan menghubungkan materi baru yang dipelajari dengan pengetahuan sebelumnya mengalami peningkatan paling besar yaitu sebesar $12,5 \%$. Menurut peserta didik, dalam menghubungkan materi baru dengan pengetahuan sebelum-nya memang sulit, tetapi setelah terbiasa maka itu akan menjadi mudah. Materi fisika yang diterima ternyata selalu berhubungan dengan materi-materi sebelumnya. Sehingga peserta didik mampu menghubungkan materi yang baru dengan sesuatu yang telah diketahui sebelumnya dengan mudah. Misalnya ketika sedang membahas Azas Black, pesertadidik mampu untuk menghubungkannya dengan konsep suhu yang telah diketahui sebelumnya.

Berdasarkan hasil angket pada tabel 2, indikator kemampuan menghubungkan materi yang dipelajari dengan salah satu ayat dalam Al-Qur'an pada siklus 1 ke siklus 2 juga mengalami peningkatan lumayan besar yaitu sebesar $9 \%$. Peserta didik yang sebagian besar adalah berasal dari sekolah umum ini ternyata mampu untuk mengintegrasikan salah satu ayat Al-Qur'an dengan materi yang sedang dipelajari. Peserta didik mampu menjelaskan keterkaitan antara kandungan Ayat Al-Qur'an yang disebutkan dengan materi yang sedang dipelajarinya dengan sangat baik. Misalnya ketika peserta didik mempelajari materi gelombang, ayat Al-Qur'an yang sesuai adalah Ayat 46 surat Ar Ruum :" Dan diantara tanda -tanda kekuasaan-Nya ialah bahwa Dia mengirimkan angin sebagai pembawa berita gembira dan untuk merasakan kepadamu sebagian dari rahmat-Nya dan supaya kapal dapat berlayar dengan perintah-Nya dan supaya kamu dapat mencari karuniaNya, mudahmudahan kamu bersyukur." Berdasarkan kandungan ayat tersebut "angin" yang dimaksud adalah angin yang bertiup membawa awan untuk menurunkan air hujan dan angin yang meniup kapal layar agar dapat berlayar dilautan, dapat diartikan makna "angin" dalam ayat ini adalah gelombang, bukan saja gelombang bunyi yang membawa berita tetapi juga gelombang radio atau gelombang cahaya yang mampu dipancarkan kesegala penjuru dunia bahkan seluruh jagad raya ini.

Berdasarkan hasil angket pada tabel 2, indikator kemampuan mengaplikasikan materi yang dipelajari dalam kehidupan sehari-harimengalami peningkatan dari siklus 1 ke siklus 2 sebesar 6,5\%. Peserta didik sangat antusias ketika diminta untuk memberikan contoh aplikasi materi dalam kehidupan seharihari yang biasa mereka alami atau mereka jumpai. Dengan hal ini, maka ketika siklus 1 pembelajaran meng-gunakan diagram Vee mulai diterapkan peserta didik tidak mengalami kesulitan untuk melengkapi diagram Vee pada bagian aplikasi materi dalam kehidupan sehari-hari. Ternyata 
peserta didik merasa sangat senang ketika materi yang sedang dipela-jarinya ada kaitannya dengan peristiwa yang terjadi dalam kehidupan sehari-hari yang sering mereka jumpai. Misalnya ketika membahas materi fluida, ketika berenang, menyelam, menggunakan parfum ataupun penyemprot obat nyamuk dsb ternyata itu ada hubungannya dengan materi fluida.

Secara keseluruhan, hasil penelitian ini menunjukkan bahwa semakin lama peserta didik merasakan pembelajaran yang dialaminya sangat bermakna. Pada mulanya peserta didik bingung dengan pembelajaran yang dilakukan, apalagi ketika pertama kali peserta didik diminta untuk menyelesaikan diagram Vee. Tetapi dengan dilakukan secara berulang-ulang, peserta didik semakin memahami apa yang harus dilakukannya. Peserta didik juga semakin memahami maksud pendidik memberikan diagram Vee dan meminta mengkaitkan ayat AlQur'an dengan materi yang sedang dipelajari. Melalui mengintegrasikan materi fisika dengan ayat Al-Qur'an yang sesuai peserta didik lebih menghargai dan meyakini keteraturan alam ciptaan Tuhan. Hal ini sesuai dengan tujuan pendidikan IPA di Indonesia yaitu agar peserta didik memiliki keyakinan keteraturan alam ciptaan-Nya dan keagungan Tuhan Yang Maha Esa ${ }^{13}$.

Setelah mengalami pembelajaran ini, pengetahuan peserta didik semakin berkembang dan mampu tersimpanlama di pikirannya. Selain itu, peserta didik juga

\footnotetext{
${ }^{13}$ Pusat Kurikulum Penelitian dan Pengembangan Depdiknas, "Kurikulum Berbasis Kompetensi Mata Pelajaran Fisika Sekolah Lanjutan Pertama," 2001, http://www.infokursus.net/download/0602131059KB K_musik_Diknas_2009.pdf.
}

semakin mengetahui ternyata banyak ayat-ayat Al-Qur'an yang memerintahkan agar manusia memikirkan sebagian tandatanda kebesaran dan keagungan-Nya melalui penciptaan langit dan bumi, juga berbagai fenomena dan peristiwa alam ${ }^{14}$. Peserta didik juga semakin paham atas tujuan dan fungsi pembelajaran Fisika Dasar yang telah dilakukan. Tujuan dan fungsi yang dimaksud adalah menyadari keteraturan alam, mengagungkan kebesaran Allah SWT, memupuk sikap ilmiah, memahami konsep-konsep fisika dan keterkaitannya dan penerapannya untuk menyelesaikan masalah dalam kehidupan sehari-hari, dan membentuk sikap positif untuk semakin tertarik mempelajari fisika karena berhubungan dengan gejala kehidupan di alam.

\section{E. PENUTUP}

Penelitian yang dilakukan ini mempunyai kesimpulan, yaitu:

Pembelajaran Fisika Dasar dengan diagram Vee ini mampu meningkatkan kemampuan peserta didik dalam menghubungkan materi baru yang dipelajari dengan pengetahuan sebelumnya pada materi kesetimbangan benda tegar, kalor, fluida dan gelombang sebesar 12,5\%. (2) Pembelajaran Fisika Dasar dengan diagram Vee ini mampu meningkatkan kemampuan peserta didik dalam mengaplikasikan materi yang dipelajari dalam kehidupan sehari-hari pada materi kesetimbangan benda tegar, kalor, fluida dan gelombang sebesar 6,5\%.

\footnotetext{
${ }^{14}$ Djudin Tomo, “Menyisipkan Nilai-Nilai Agama Dalam Pembelajaran Sains: Suatu Alternatif Memagari Keimanan Siswa," Jurnal Program Studi FKIP Fisika, Universitas Tanjungpura) Tanjungpura: Universitas Tanjungpura, 2012.
} 
Pembelajaran Fisika Dasar dengan diagram Vee ini mampu meningkatkan kemampuan menghubung-kan materi yang dipelajari dengan salah satu ayat dalam Al-Qur'an pada materi kesetimbangan benda tegar, kalor, fluida dan gelombang sebesar 9\%.

Pembelajaran Fisika Dasar dengan diagram Vee ini mampu meningkatkankemampuan menemukan jawaban sendiri dari suatu permasalahan yang ada pada materi kesetimbangan benda tegar, kalor, fluida dan gelombang sebesar 0,6\%. (5) Pembelajaran Fisika Dasar dengan diagram Vee ini mampu menciptakan pembelajaran bermakna pada kategori baik pada siklus 1, dengan persentase $74,5 \%$ dan kategori baik sekali pada siklus 2 yaitu dengan persentase 82,7\%. Berdasarkan hal ini maka pembelajaran Fisika Dasar dengan diagram Vee ini jika dilakukan secara terus menerus maka pembelajaran yang ada di kelas akan bermakna. Peserta didik juga akan mempunyai pengalaman baru dalam mempelajari suatu materi fisika dan mampu mengembangkan materi yang didapat dalam kehidupan sehari-hari ataupun diluar fisika.

Berdasarkan hasil penelitian dan pembahasan maka dapat dikemukakan beberapa saran, yaitu: (1) Pembelajaran Fisika Dasar dengan diagram Vee ini tidak hanya dilakukan pada empat pertemuan, tetapi lebih sering diimplementasikan akan lebih baik meskipun dibutuhkan waktu lebih lama daripada pembelajaran biasa. (2) Setelah dilakukan pembelajaran yang sebagian besar berpusat pada peserta didik, hendaknya setelah itu pendidik memberikan penguatan dengan mengulas kembali materi yang telah dibahas bersama, hal ini agar pengetahuan yang telah diperoleh peserta didik semakin tersimpan rapi di pikiran. (3) Pada pembelajaran Fisika Dasar dibutuhkan bahan ajar yang terintegrasi nilai-nilai ayat Al-Qur'an pada setiap materi nya, agar pembelajaran berlangsung dengan baik dan maksimal dalam membahas hubungan materi fisika yang sedang dipelajari dengan nilai-nilai pendidikan islam yang terkandung dalam ayat Al-Qur'an.

\section{F. DAFTAR RUJUKAN}

Bawaneh, Ali Khalid Ali, Ahmad Nurulazam Md Zain, and Munirah Ghazali. "The Effectiveness of Conflict Maps and the V-Shape Teaching Method in Science Conceptual Change among EighthGrade Students in Jordan." International Education Studies 3, no. 1 (2010): 96.

DEPDIKNAS. "Undang-Undang RI No 29 Pasal 1 Tahun 2003." DEPDIKNAS, 2003.

Depdiknas, Pusat Kurikulum Penelitian dan Pengembangan. "Kurikulum Berbasis Kompetensi Mata Pelajaran Fisika Sekolah Lanjutan Pertama," 2001. http://www.infokursus.net/downl oad/0602131059KBK_musik_Dikn as_2009.pdf.

Karli, H dan Sriyuliaratnaningsih. Implementasi Kurikulum Berbasis Kompetensi. Bandung: Rosdakarya, 2004.

Keleş, Özgül, and Sibel Özsoy. "Pre-Service Teachers' Attitudes toward Use of 
Vee Diagrams in General Physics Laboratory." International Electronic Journal Environmental Education 1, no. 3 (2009). http://dergipark.ulakbim.gov.tr/iej eegreen/article/download/500013 3234/5000122068.

Latifah, Sri, Eka Setiawati, and Abdul Basith. "Pengembangan Lembar Kerja Peserta Didik (LKPD) Berorientasi Nilai-Nilai Agama Islam Melalui Pendekatan Inkuiri Terbimbing Pada Materi Suhu Dan Kalor." Jurnal Ilmiah Pendidikan Fisika Al-Biruni 5, no. 1 (2016): 4352.

Nana, Sukmadinata Syaodih. Landasan Psikologi Proses Pendidikan. Bandung: PT Remaja Rosdakarya, 2009.

Nurhadi, Burhan Yasin, and Agus Gerrad Senduk. Pembelajaran Kontekstual Dan Penerapannya Dalam KBK. Malang: UM Press, 2004.

Patmawati. "Penerapan Model Inkuiri Dengan Siklus Belajar Dalam Pembelajaran Biologi Untuk Meningkatkan Kerja Ilmiah Dan Prestasi Belajar Kognitif Siswa Kelas XII IPA 3 SMAN Purwosari," 2006.

http://library.um.ac.id/ptk/index.p $\mathrm{hp}$ ? $\bmod =$ detail\&id=55417.

Suharsimi, Arikunto, and others. "Penelitian Tindakan Kelas." Jakarta: Bumi Aksara, 2006.

Tomo, Djudin. "Menyisipkan Nilai-Nilai Agama Dalam Pembelajaran Sains: Suatu Alternatif Memagari Keimanan Siswa." Jurnal Program Studi FKIP Fisika, Universitas
Tanjungpura) Tanjungpura:

Universitas Tanjungpura, 2012.

Utami, Budi. "Pengaruh Strategi Peta Konsep Dan Diagram Vee Terhadap Hasil Belajar Siswa Pada Pokok Bahasan Larutan Penyangga Yang Diukur Dengan Authentic Assessment.," 2009. http://karyailmiah.um.ac.id/index.php/disertas i/article/view/841. 


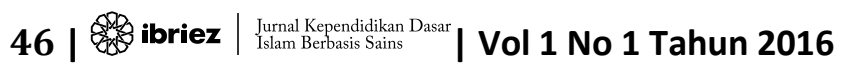

